\title{
Communication Technology and Stronger Community Alienation
}

\author{
Nurudin \\ Communication Department \\ Universitas Muhammadiyah Malang \\ Malang, Indonesia \\ nurud70@yahoo.com
}

\begin{abstract}
This research background consists of some aspects: (1) communication technology development which increases rapidly, (2) technology influences society's attitude and behavior, (3) the society's alienation existence of technology product. The research problem which proposed was "how is the communication technology development build society's alienation?'. In addition, the research subject was the permanent reporter of Bestari newspaper at University of Muhammadiyah Malang (UMM). Malang was become the research location. The data were collected by interview and documentation, while the analysis implemented was individual analysis. However, the research method was quantitative with individual analysis unit; focused on the research subjects' attitude and behavior which influenced by the communication technology development. Then, the analysis interactive was applied to analyze the data. The findings of this research were; (1) technology strengthened the human dependency to be alien of their social environment; (2) technology caused the social relationship be mechanical; (3) human alienation that was influenced by the technology capitalization developing to the commodity.
\end{abstract}

\section{Keywords-Alienation, communication technology, society}

\section{INTRODUCTION}

The communication technology develops rapidly. It development changes and influences some varieties of society's behavior. However, the changes can be planned because the technology possibly created spontaneously. The changes planned existences because of the human have desire to change it. Hence, the human created technology which can easier their activities. It is a proof that the society's changes were planned; it can be existence because of human plan to change by using technology mediator.

In other hand, the unplanned changes can be seen from the human; they do not make a plan. In other word, the changes happen naturally. It changes are related to the communication technology development. As an example, an individual relies on technology like a smart phone. It is happened spontaneously because human needs to communicate easier. The main purpose is to easier the daily activities. [1]

Because of its easier, human relies on the smart phone and it changes their activities spontaneously. Human feels uncomfortable where they do not take advantage of technology. That is the reality of unplanned changes.
Technology influences the alienation which existence in the society. In etymology, alienation has three meanings: (1) as an owner transition, (2) as a mental disorder, and (3) niter-personal alienation. The alienation as an owner transition comes from the alinenare concept (transfers the ownership to others). However, the alienation as a mental disorder comes from the word alienaire (causes the cool down relationship with other; causes the separation; causes someone being hated)

One of the interesting knowledge from Marx about capitalism is related to the alienation. Capitalism causes someone faces alienation because of the producer creativity result is sequestered from its producer. In marx opinion, alienation can take some parts; (1) unmanaged product of the producer such as type, quality, cost, and marketing; (2) the producer must control their self-such as follow the machine producer capacity [2]. In its development, technology become unfamiliar (alien) to human; perforated and the human becomes independent. [3]

Guy Debord (1967) calls it a society of the spectacle. It is a stage for a certain commodity after successfully colonizing a social life completely. The commodification is not just those that visible, but we cannot see anything because what we actually see is the world of commodities. Alienation in the society of the spectacle occurs because of the images that represented by the commodity affect the public as social life. This process occurs unconsciously and becomes an individual reflection in behaving. The more an individual contemplates or projects themselves on the objects that reflecting a "needs", the more they identify themselves with those images. As a result, they will be farther away from themselves. They will not understand their life and their own desire. Actions and behavior (gestures) of the subject no longer reflect themselves, but other people gesture that represented through themselves. [4]

Alienation also occurs among humans. Alienation between humans is a form of a consequence of the alienation of production. In the capitalist economic system, the worker is not allowed to work cooperatively. Capitalist make them work individually and even they have to compete for who work better and how far they produce. This term makes them see other workers as a competitor or even as an enemy. They do not know each other, even though they work in the same place. In civil society, Marx said that alienation among humans can be interpreted as a valuation towards fellow human beings that 
no longer has positive significance other than to achieve personal goals.

This research analyzes the correlation between communication technology development and the society's changes. The research problem which proposed is "how is the communication technology development build society's alienation?'.

\section{METHOD}

This research applied qualitative method. According to Bogdan and Taylor, qualitative method is a research procedure which produces descriptive information in a form of written or spoken words of people and behavior being observed [5]. Qualitative method is a certain tradition in social science; where fundamentally relies on the observation to the human of his knowledge and the relation with other people in his language [6].

The research subject was the permanent reporter of Bestari newspaper at University of Muhammadiyah Malang (UMM). Malang was become the research location. The data were collected by interview and documentation, while the analysis unit implemented was individual analysis.

Furthermore, the data analyses consisted of managed, arranged, and classified; gave a code and categorized it. Data analyses process begun from analyzed the data which taken from several sources such as: interview, book, tabloid, newspaper, etc. Beside it was read and analyzed; it was being reduction by writing abstract. Abstract is an effort of writing the main conclusion. Hence, the process and its questions should be managed properly. The analysis method as explained above was an analysis of interactive model by Mattew B. Miles and A. Michael Huberman. [7]

\section{RESULT AND DISCUSSION}

Communication technology development had a significant influence to the society attitude and behavior. However, the communication technology became the guidance of the society to do something. In this modern era, all the changes were determined by the technology. Therefore, the human relied on technology.

The high level of human dependency on technology was approved by the research subjects. Some of them argue that they cannot ignore the communication technology result. The needed of its technology influenced the society attitude and behavior. One of the realities found was: the human activities schedule was managed by the technology. They could imagine a day without using communication technology such as smart phone.

In fact, technology was a product where human as it producer. Because of it, technology depended on human desire and it influenced human to rely on it. Human were no longer independent to control technology and the technology became the determinant factor of human choice and activity.

This phenomenon claimed the human was unfamiliar with technology (alien). However, the technology was a product of human (as a producer). If it was analyse continuously, alienation of technology influence human to be unfamiliar with their environment. Individually, the technology became alien; and in its development, the society became the alien of each individual

Some subjects stated that the alienation was strengthened by the social media existence. The media created aliens in human environment. It happened because the technology had become the human commodity. Human got the advantages of technology, but human became the alien of their social environment.

In the end, technology will also damage the relationship between humans. Which means, the relationship between humans is mechanical. In the study of communication, it can be called the commodification of information. In other words, information has become merchandise. Information on a commodity where everyone who wants to get it, they have to pay.

As a result, the impact of technology makes the relationship between humans will be empty. Physical social gatherings have an intimate relations impact. People meet each other and see each other's expressions. The expressed message can be verbally and non-verbally accepted. Technology makes individual alienation empty because communication messages can only be interpreted in terms that appear only on the surface.

\section{CONCLUSION}

Technology influenced human to rely on it. This dependency possible to make human aliens; not only on technology but also in social environment. The technology developed and damaged human relation to others. Hence, the relation did by the human in mechanical because of technology dependency. The alienation was influenced by the technology capitalism which developed as commodity. In other word, media social was an example of communication technology commodity.

\section{REFERENCES}

[1] Nurudin, Perkembangan Teknologi Komunikasi, Jakarta: Rajawali Pers, 2017.

[2] Damsar, Pengantar Teori Sosiologi, Jakarta: Kencana, 2015.

[3] R. Schacht, Alienasi, Yogyakarta: Jalasutra , 2009.

[4] A. Permana, "Gejala Alienasi dalam Masyarakat Konsumeristik," Jurnal Pemikiran Sosiologi Vol 1 nomor 2, pp. 91-107, 2012.

[5] L. J. Moleong, Metodologi Penelitian Kualitatif, Bandung: Rosda, 2012

[6] J. W. Creswell, Qualitative Inquiry \& Research Design, Choosing Among Five Aprroach, California: Sage Publication, 2011.

[7] Emzir, Metodologi Penelitian Kalitatif Analisis Data, Jakarta: RajaGrafindo Persada, 2016. 